\title{
HUBUNGAN TINGKAT PENDIDIKAN MASYARAKAT TERHADAP PENGETAHUAN DALAM PENGGUNAAN ANTIBIOTIK ORAL DI APOTEK KECAMATAN KOTO TANGAH PADANG
}

\author{
Ringga Novelni ${ }^{1 *}$, Lola Azyenela ${ }^{1}$, Yola Septiana ${ }^{1}$ \\ ${ }^{1 *}$ Universitas Perintis Indonesia \\ e-mail : ringga.novelni@gmail.com
}

\begin{abstract}
ABSTRAK
Antibiotik merupakan obat yang banyak digunakan untuk terapi pengobatan infeksi, namun kini pembelian antibiotik tanpa resep dokter di apotek telah menjadi masalah global khususnya di negara berkembang. Penelitian ini bertujuan untuk mengetahui hubungan tingkat pendidikan masyarakat terhadap pengetahuan dalam penggunaan antibiotik oral pada apotek di Kecamatan Koto Tangah Padang. Metode yang digunakan adalah deskriptif korelatif dengan pendekatan cross-sectional. Populasi pada penelitian ini adalah seluruh masyarakat yang berkunjung ke apotek di Kecamatan Koto Tangah. Teknik pengambilan sampel menggunakan teknik non random sampling yaitu secara purposive sampling sejumlah 100 responden yang telah memenuhi kriteria inklusi dan eksklusi. Alat ukur dalam penelitian ini menggunakan kuesioner tentang pengetahuan dalam penggunaan antibiotik oral. Berdasarkan hasil uji statistik chi-square antara tingkat pengetahuan dan tingkat pendidikan diperoleh $\mathrm{p}=0,000$. Hal ini menunjukkan nilai $\mathrm{p}$ tidak lebih besar dari 0,05 , dan hubungan antara tingkat pendidikan masyarakat dengan pengetahuan dalam penggunaan Antibiotik Oral dengan uji korelasi Spearman adalah sebesar 0,53, sehingga dapat disimpulkan bahwa terdapat hubungan antara tingkat pengatahuan masyarakat dalam pengetahuan penggunaan antibiotik oral
\end{abstract}

Kata Kunci: Antibiotik, Pendidikan, Pengetahuan, Apotek.

\begin{abstract}
Antibiotics are drugs that are widely used for therapeutic treatment of infections, but now the purchase of antibiotics without a doctor's prescription at pharmacies has become a global problem, especially in developing countries. This study aims to determine the relationship of community education level to knowledge in the use of oral antibiotics in pharmacies in Koto Tangah District, Padang. The method used is descriptive correlative with cross-sectional approach. The population in this study were all people who visited the pharmacy in Koto Tangah District. The sampling technique uses non-random sampling technique that is purposive sampling of 100 respondents who have met the inclusion and exclusion criteria. Measuring instruments in this study used a questionnaire about knowledge in the use of oral antibiotics. Based on the results of the chi-square statistical test between the level of knowledge and the level of education obtained $\mathrm{p}=0,000$. This shows the $\mathrm{p}$ value is not greater than 0.05 , and the relationship between the level of public education with knowledge in the use of Oral Antibiotics with the Spearman correlation test is 0.53 , so it can be concluded that there is a relationship between the level of public knowledge and the level of public education in use of oral antibiotics.
\end{abstract}

Keywords : Antibiotics, Education, Knowledge, Pharmacy. 


\section{PENDAHULUAN}

Antibiotik merupakan obat yang paling banyak digunakan pada infeksi yang disebabkan oleh bakteri di mana antibiotik rute per oral merupakan pilihan pertama pada terapi infeksi. Berbagai studi menemukan bahwa sekitar 40-62\% antibiotik digunakan secara tidak tepat, antara lain untuk penyakit-penyakit yang sebenarnya tidak memerlukan antibiotik, seperti influenza (Kemenkes, 2011).

Tingginya penggunaan antibiotik yang tidak tepat pada masyarakat menyebabkan terjadinya masalah resistensi antibiotik. Hasil penelitian Antimicrobial Resistant in Indonesia (AMRINStudy) menunjukkan bukti bahwa dari 2.494 individu di masyarakat $43 \%$ Escherichia coli resisten terhadap berbagai jenis antibiotik, antara lain: Ampicilline (34\%), Cotrimoxazole (29\%), dan Chloramphenicol (25\%) (Permenkes RI, 2011). Permasalahan resistensi ini mengakibatkan turun atau hilangnya efektivitas obat atau senyawa kimia yang berguna untuk mencegah atau mengobati infeksi (Febiana et al., 2012).

Salah satu faktor yang menyebabkan terjadinya resistensi yaitu penyedia obat memberikan pelayanan pembelian antibiotik secara bebas, sehingga masyarakat dapat dengan mudah membeli antibiotik tanpa resep dokter. Pada penelitian yang dilakukan di Brazil menunjukkan bahwa 74\% dari 107 apotek yang telah dikunjungi, termasuk 88\% apotek yang didaftar oleh Municipal Health Secretary menjual antibiotik tanpa resep dokter (Volpato et al., 2005). Hasil penelitian yang dilakukan oleh Fernandez (2013) di Kabupaten Manggarai dan Manggarai Barat, Provinsi Nusa Tenggara Timur menyatakan bahwa jenis antibiotik yang sering dibeli tanpa resep adalah Amoxycilline (80.56\%), Ampicilline (9.26\%), Ciprofloxacin $(2.78 \%)$, Cefalexin $(1.85 \%)$, Cefadroxil $(1.85 \%)$, dan Tetrasiklin $(3.70 \%)$.

Faktor lainnya yang menyebabkan terjadinya resistensi antibiotik karena kurangnya pengetahuan dalam menggunakan antibiotik, sehingga masyarakat mengkonsumsi antibiotik secara tidak tepat dan tidak sampai habis dengan alasan sudah sembuh (Kemenkes, 2011). Pada penelitian yang dilakukan Ihsan (2016) di Kota Kendari, Provinsi Sulawesi Tenggara, tentang tingkat pengetahuan responden terkait penggunaan antibiotik tanpa resep, sebagian besar termasuk kategori rendah $(56,44 \%)$, penyakit yang diobati terbanyak untuk demam 54,34\% dengan jenis antibiotik terbanyak adalah amoksisilin dengan penggunaan sekali.

Pengetahuan sangat dipengaruhi oleh pendidikan. Masyarakat yang memiliki pendidikan lebih tinggi, pada umumnya mempunyai pengetahuan dan wawasan yang luas sehingga lebih mudah menyerap dan menerima informasi (Widayati et al, 2012).
Berdasarkan data rekapitulasi Dinas Kesehatan Kota Padang dimana terdapat 200 apotek yang terdaftar di Kota Padang. Pada kecamatan Koto Tangah terdapat 16 apotek yang terdaftar, 5 diantaranya memiliki kunjungan pembelian antibiotik oral yang paling tinggi di Kecamatan Koto Tangah, dengan jumlah kunjungan rata-rata diatas 10 pembelian antibiotik oral per-harinya, data ini didapatkan berdasarkan hasil survei pada bulan Juni 2019.

Berdasarkan uraian di atas, peneliti tertarik melakukan penelitian untuk mengetahui adanya pengaruh pendidikan dengan pengetahuan dalam penggunaan Antibiotik Oral pada apotek di Kecamatan Koto Tangah Padang.

\section{METODE PENELITIAN}

Pengambilan data penelitian dilaksanakan pada bulan Juli - September 2019. Jenis penelitian ini adalah deskriptif korelatif, dengan desain penelitian cross sectional.

\section{Populasi}

Populasi yang diteliti dalam penelitian ini adalah seluruh masyarakat yang berkunjung ke apotek di Kecamatan Koto Tangah.

\section{Sampel}

Masyarakat yang membeli antibiotik oral tanpa resep pada apotek di Kecamatan Koto Tangah Padang yang memenuhi kriteria inklusi.

\section{Kriteria Inklusi dan Eksklusi}

a. Kriteria Inklusi

1. Masyarakat berusia 20 tahun ke atas.

2. Masyarakat yang membeli antibiotik tanpa resep.

3. Masyarakat yang mau bekerjasama dalam penelitian.

4. Masyarakat yang dapat menulis dan membaca.

b. Kriteria Eksklusi

1. Masyarakat dengan latar belakang pendidikan kesehatan.

\section{Instrumen Penelitian}

Instrumen yang digunakan untuk penelitian ini adalah kuesioner: Kuesioner bagian I pertanyaan tentang demografi, kuesioner bagian II berisikan 15 pernyataan tentang pengetahuan masyarakat dalam menggunakan antibiotik oral.

Sebelum digunakan kuesioner dilakukan uji validitas dan reliabilitas. 


\section{Uji Validitas}

Dilakukan dengan Korelasi Pearson Product Moment, dengan melakukan pilot study pada 25 orang responden.

\section{Uji Reliabilitas}

Dilakukan pada pernyataan yang telah valid menggunakan teknik cronbach alpha.

\section{Uji Bivariat}

Data dianalisis bivariat untuk melihat hubungan antara variabel independent yaitu pendidikan dan variabel dependent yaitu pengetahuan. Analisis yang digunakan adalah uji nonparametrik Chi square. Suatu variabel dikatakan memperngaruhi variabel lainnya jika nilai $p$-value < 0,05 dengan interval kepercayaan 95\% (Notoatmodjo, 2010). Analisis lain yang digunakan adalah uji korelasi Spearman, untuk melihat kekuatan hubungan faktor sosiodemografi terhadap pengetahuan. Jika nilai signifikansi $<0.05$, menunjukkan adanya hubungan yang bermakna antara 2 variabel. Sebaliknya, jika nilai signifikansi > 0.05, maka tidak ada hubungan yang bermakna antara 2 variabel (Dahlan, 2012).

\section{HASIL DAN PEMBAHASAN}

Tabel 1. Hubungan antara faktor sosiodemografi dengan pengetahuan

\begin{tabular}{ccccc}
\hline No. & Faktor Sosiodemografi & $\begin{array}{c}\text { Korelasi } \\
\text { Spearman }\end{array}$ & Nilai Sig. & $\begin{array}{c}\text { Kekuatan Hubungan } \\
\text { dengan Pengetahuan }\end{array}$ \\
\hline 1. & Jenis Kelamin & 0.29 & 0.003 & Hubungan Lemah \\
2. & Pekerjaan & 0.20 & 0.001 & Hubungan Lemah \\
3. & Penddikan & 0.53 & 0.000 & Hubungan Kuat \\
\hline
\end{tabular}

Menurut interpretasi koefisien korelasi versi de Vaus dikatakan hubungan lemah jika berada pada rentang 0.10-0.29, dikatakan terdapat hubungan kuat jika berada pada rentang 0.50-0.69. Pada tabel 6 dapat dilihat nilai signifikansi yang didapatkan dalam penelitian ini kecil dari taraf signifikansi yakni $<0.05$ yang berarti menunjukan adanya hubungan yang bermakna antara faktor sosiodemografi (jenis kelamin, pekerjaan, pendidikan) dengan pengetahuan.

\section{Deskripsi Jawaban Responden}

Tingkat pengetahuan masyarakat dalam menggunakan Antibiotik Oral tergolong cukup yaitu $71,2 \%$. Berdasarkan data yang diperoleh sebagian pernyataan yang terdapat pada kuesioner dijawab dengan benar. Data lengkap distribusi jawaban dari responden dapat dilihat pada tabel 2 .

Tabel 2. Persentase Jawaban Pernyataan Responden

\begin{tabular}{|c|c|c|c|}
\hline No. & Daftar Pernyataan & Ya $(\%)$ & Tidak $(\%)$ \\
\hline 1. & Antibiotik adalah obat yang berkhasiat membunuh kuman atau bakteri. & $87 \%$ & $13 \%$ \\
\hline 2. & $\begin{array}{l}\text { Antibiotik termasuk golongan obat keras, obat yang hanya bisa diperoleh dengan resep } \\
\text { dokter. }\end{array}$ & $57 \%$ & $43 \%$ \\
\hline 3. & Antibiotik tidak dapat digunakan untuk mengobati segala jenis penyakit. & $64 \%$ & $36 \%$ \\
\hline 4. & Pemilihan antibiotik disesuaikan dengan jenis penyakit. & $88 \%$ & $12 \%$ \\
\hline 5. & Antibiotik tidak boleh diminum sekali saja atau 1 tablet saja. & $66 \%$ & $34 \%$ \\
\hline 6. & $\begin{array}{l}\text { Antibiotik yang digunakan tidak sesuai anjuran dokter bisa menimbulkan resistensi } \\
\text { (kekebalan) bakteri. }\end{array}$ & $67 \%$ & $33 \%$ \\
\hline 7. & $\begin{array}{l}\text { Jika terjadi resistensi atau kekebalan bakteri terhadap antibiotik, maka tidak dapat } \\
\text { diobati dengan antibiotik yang sama. }\end{array}$ & $54 \%$ & $46 \%$ \\
\hline 8. & $\begin{array}{l}\text { Penyimpanan antibiotik yang baik harus terhindar dari cahaya matahari secara } \\
\text { langsung. }\end{array}$ & $90 \%$ & $10 \%$ \\
\hline 9. & $\begin{array}{l}\text { Antibiotik tidak boleh diminum bersama susu, teh atau kopi untuk mengurangi rasa } \\
\text { pahit. }\end{array}$ & $69 \%$ & $31 \%$ \\
\hline 10. & Antibiotik harus digunakan sesuai dosis yang dianjurkan oleh dokter. & $83 \%$ & $17 \%$ \\
\hline 11. & Antibiotik tidak dapat digunakan untuk mengatasi infeksi akibat virus, seperti flu. & $59 \%$ & $41 \%$ \\
\hline 12. & Antibiotik boleh diminum hanya untuk penyakit yang disebabkan oleh bakteri. & $65 \%$ & $35 \%$ \\
\hline 13. & Jika merasa sudah sembuh, maka penggunaan antibiotik harus tetap dihabiskan. & $64 \%$ & $36 \%$ \\
\hline 14. & Antibiotik yang bersisa tidak boleh digunakan kembali ketika sakit. & $65 \%$ & $35 \%$ \\
\hline 15. & Penggunaan antibiotik yang tidak tepat dapat membahayakan penggunanya. & $90 \%$ & $10 \%$ \\
\hline
\end{tabular}


Dari hasil jawaban responden dapat diketahui tingkat pengetahuan rendah terdapat 1 pernyataan yaitu pada pernyataan 7 , bahwa jika terjadi resistensi atau kekebalan bakteri terhadap antibiotik.

maka tidak dapat diobati dengan antibiotik yang sama, dikatakan rendah karena persentase yang di dapat $<55 \%$. Hal ini terjadi karena masyarakat tdak memahami makna dari resistensi antibiotik dan tidak menyadari bahwa antibiotik tersebut tidak lagi bermanfaat baginya.

Tingkat pengetahuan cukup terdapat 9 pernyataan yaitu pernyataan 2 , pernyataan 3 , pernyataan 5 , pernyataan 6 , pernyataan 9 , pernyataan 11 , pernyataan 12 , pernyataan 13 , pernyataan 14 . Dikatakan cukup karena persentase yang didapatkan melebihi dari 56\%. Hal ini berarti sebagian besar masyarakat yang menggunakan antibiotik belum terlalu memahami tentang golongan antibiotik dan cara penggunaan antibiotik dengan benar.

Tingkat pengetahuan masyarakat yang tinggi terdapat 5 pernyataan yaitu pernyataan 1 , pernyataan 4, pernyataan 8 , pernyataan 10 , pernyataan 15, dikatakan tinggi karena hasil yang didapatkan melebihi $76 \%$. Hal ini berarti sebagian besar masyarakat sudah mengetahui defenisi dari antibiotik, pemilihan antibiotik yang tepat untuk penyakit, bagaimana penyimpanan antibiotik yang baik, antibiotik harus digunakan sesuai dosis yang dianjurkan oleh dokter, dan bahaya dari penggunaan antibiotik yang tidak tepat.

\section{Hubungan Antara Tingkat Pengetahuan dalam Penggunaan Antibiotik Oral dan Tingkat Pendidikan}

Tabel 3. Hubungan Antara Tingkat Pengetahuan dalam Penggunaan Antibiotik Oral dan Tingkat Pendidikan

\begin{tabular}{|c|c|c|c|c|}
\hline \multirow{2}{*}{ Tingkat Pendidikan } & \multicolumn{2}{|c|}{$\begin{array}{c}\text { Tingkat } \\
\text { Pengetahuan }\end{array}$} & \multirow{2}{*}{$\begin{array}{c}\text { Jumlah } \\
\mathbf{N}\end{array}$} & \multirow{2}{*}{ Nilai $\mathbf{p}$} \\
\hline & $\begin{array}{c}\mathbf{Y a} \\
\mathbf{N}\end{array}$ & $\begin{array}{c}\text { Tidak } \\
\mathbf{N}\end{array}$ & & \\
\hline SD & 2 & 12 & 14 & \\
\hline SMP & 3 & 12 & 15 & \\
\hline SMA & 27 & 11 & 38 & 0.000 \\
\hline PT & 28 & 5 & 33 & \\
\hline Total & 60 & 40 & 100 & \\
\hline
\end{tabular}

Pada tabel 3 dapat dilihat masyarakat yang mengetahui penggunaan Antibiotik Oral yang tinggi dengan latar belakang pendidikan Perguruan Tinggi (PT) sebesar $85 \%$, kemudian disusul dengan latar belakang pendidikan SMA $71 \%$. Sedangkan masyarakat dengan latar belakang pendidikan SMP dan SD yang mengetahui penggunaan Antibiotik Oral berturut-turut $20 \%$ dan $14 \%$. Masyarakat yang berpendidikan rendah cenderung memiliki pengetahuan yang rendah, sedangkan semakin tinggi tingkat pendidikan maka memungkinkan semakin baik pula pengetahuan masyarakat.

Selanjutnya, untuk melihat apakah terdapat hubungan antara tingkat pengetahuan masyarakat dan tingkat pendidikan masyarakat secara statistik maka dianalisis menggunakan Uji Chi Square. Berdasarkan Tabel 7 terlihat bahwa nilai $\mathrm{p}=0.00$. Nilai ini kurang dari 0,05 sehingga dapat disimpulkan terdapat hubungan antara tingkat pendidikan dengan pengetahuan masyarakat dalam penggunaan Antibiotik Oral. Hal ini dapat diartikan bahwa tingkat pendidikan masyarakat mempengaruhi pengetahuan dalam penggunaan antibiotik oral.

Untuk mengetahui kekuatan hubungan antara tingkat pendidikan masyarakat dengan pengetahuan dalam penggunaan Antibiotik Oral dilakukan uji korelasi Spearman (Tabel 1) dengan hasil sebesar 0.53 . Nilai ini menunjukan hubungan yang kuat antara tingkat pendidikan dengan pengetahuan dalam penggunaan antibiotik oral, dikatakan kuat karena menurut interpretasi koefisien korelasi versi de Vaus dikatakan terdapat hubungan kuat jika berada pada rentang 0.50-0.69.

Berdasarkan hasil penelitian oleh So Sun et al pada tahun 2011 di Korea Selatan menunjukkan bahwa responden yang telah lulus perguruan tinggi 2.39 kali lebih tinggi memiliki kesadaran mengenai penggunaan antibiotika yang benar dibandingkan dengan responden dengan tingkat pendidikan dasar. Studi lain yang dilakukan oleh Widayati et al. pada tahun 2012 juga mengatakan bahwa pendidikan sangat berpengaruh terhadap pengetahuan. Semakin tinggi tingkat pendidikan seseorang, semakin mudah orang tersebut menerima informasi.

\section{KESIMPULAN}

Pengetahuan masyarakat dalam penggunaan Antibiotik Oral memiliki hubungan dengan pendidikan masyarakat. Hubungan antara kedua variabel tersebut diukur dengan uji korelasi Spearman didapatkan hasil sebesar 0.53, artinya kedua variabel tersebut memiliki hubungan yang kuat. 


\section{DAFTAR PUSTAKA}

Badan Pusat Statistika. 2018. Padang Dalam Angka 2018. Padang : Badan Pusat Statistik.

Dahlan, Sopiyudin M. 2012. Statistik untuk Kedokteran dan Kesehatan Edisi Kelima. Jakarta: Salemba Medika.

Febiana, Tia. 2012. Kajian Rasionalitas Penggunaan Antibiotik di Bangsal Anak RSUP Dr. Kariadi Semarang Periode Agustus - Desember 2011. Tugas Akhir. Semarang: Fakultas Kedokteran Universitas Diponegoro.

Fernandez, Beatrix Anna M. 2013. Studi Penggunaan Antibiotik Tanpa Resep Di Kabupaten Manggarai dan Manggarai Barat - NTT. Jurnal Ilmiah Mahasiswa. Universitas Surabaya. 2(2): 2-3.

Ihsan, S., Kartina., Nur, I.A. 2016. Studi Penggunaan Antibiotik Non Resep di Apotek Komunitas Kota Kendari. Jurnal Farmasi. 13(2): 272-273.

Kementerian Kesehatan RI. 2011. Peraturan Menteri Kesehatan Nomor 2406/Menkes/ Per/ XII/ 2011 tentang Pedoman Umum Penggunaan Antibiotik. Jakarta: Direktorat Jendral Bina Kefarmasian dan Alat Kesehatan.

Kotler, Philip (2000). Prinsip - Prinsip Pemasaran Manajemen. Jakarta : Prenhalindo.

Notoatmodjo, Soekidjo. 2012. Promosi Kesehatan dan Perilaku Kesehatan. Jakarta. Rineka Cipta.

PERMENKES RI. 2011. Pedoman Umum Penggunaan Antibiotik, Kementrian Kesehatan RI, Jakarta, 874.

Volpato, D.E., Souza, B.V., Rosa, L.G.D., Melo, L.H., Daudt, C.A.S, and Deboni, L. 2005. Use of Antibiotics withhout Medical Prescription, BJID, 9 (4).

Notoatmodjo, Soekidjo. 2012. Promosi Kesehatan dan Perilaku Kesehatan. Jakarta. Rineka Cipta.

So Sun, Kim, M. Seongmi, dan K. E. Jung. 2011. Public Knowledge and Attitudes Regarding Antibiotic Use in South Korea. J Korean Acad Nurs. 41(6).

Widayati, A., Ari Suryawi, Charlotte de Crespigny, dan Janet E. Hiller. 2012. Knowledge and beliefs about antibiotics among people in Yogyakarta City Indonesia: Across sectional population-based survey. Antimicrobial Resistence and Infection Control 2012, 1:38. 
